\title{
Comparison in the
}

\section{localization of the feminist}

\section{narrative between China and the}

\author{
Arab countries
}

Jia Wang 


\section{Abstract:}

The female narrative appeared in the last century, and became the leading theory of academic development for the collection of classic narration and feminist literary criticism. It originated in the West in the eighties of the twentieth century, and it is an important branch of Classical Post-Narrative Studies that is currently on the rise in the international academic field. Modern and contemporary academic trends in China and the Arab countries have used feminist narratives to conduct a number of studies on women's literature and interdisciplinary phenomena. On the one hand, it complements and reinforces research methods in the western feminist narrative and introduces local research methods. On the other hand, it shows research deficiencies and obstacles as well. Therefore, studying the feminist narrative and exploring the process of localization in China and the Arab countries has great importance for both the Chinese feminist narrative and the Arab feminist narrative. This paper provides some ideas for comparing the localization of the feminist narrative in China and the Arab countries in the contemporary world.

Key words: feminist narration, narratives, feminist literature, Literary criticism 


\section{مقارنة في توطين السرد النسوي بين الصين والدول العربية الباحثة/ جيا وانج}

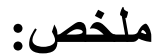

ظهر السرد النسائي في القرن الماضي، وهو النظرية الرائدة في التطور الأكاديمي للجمع بين السرد الكلاسيكي والنقد الأدبي النسوي. وقد نشـأ في الغرب في الثمانينيات من القرن العشـرين ، وهو فرع مهم من "دراســات ما بعد الســرد الكلاســـيكي" التي تتزايد حاليًا في المجالات الأكاديمية الدولية. وقد اســـتخدمت فئس الاتجاهات الأكاديمية الحديثة والمعاصـــرة في الصـــين والدول العربية الروايات النسوية لإجراء عدد من الدراسات حول أدب المرأة والظواهر متعددة التخصصات؛ فمن نـاحية ، هي تكمل وتعزز طرق البحث في الرواية النســــيـة الغربية وتقدِّم أسـاليب البحث المحلية، ومن ناحية أخرى، فإنها تُظهر أوجه القصــور والعقبات

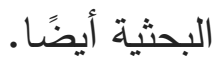

للّلك ، فإن دراسة السرد النسوي واستكشاف عملية التوطين بين الصين والدول العربية لها أهمية كبيرة لكل من السـرد النسـوي الصــيني والسـرد النســوي العربي. ويقدم هذا البحث بعض الأفكار لمقارنة توطين السرد النسوي في الصـين والدول العربية في العالم المعاصـــر، من حيث بناء النظرية ونقاط التركيز للبحث ومشاكله، وتوضيح تطور السرد النسوي بشكل مبسط. الكلمات المفتاحية: رواية نسوية ، روايات ، أدب نسوي ، نقد أدبي. 
Narrative is a basic theory developed on the basis of structuralism and used to study narrative texts. Tzvetan Todorov, who is a famous French Structuralist semiotician and literary theorist, introduced the concept of narrative first. Half a century later, narrative has become one of the important contemporary literary thoughts sweeping the world. Narration has two concepts, one of which is that the narration includes the expressional level of the narrative work, while the second concept is that: the narrative is only concerned with the narrator summarizing the dialogue movement, as it is outside the framework of the narration. $\left({ }^{1}\right)$

In short, narration is the skill of a narrator to convey information in an appropriate manner in a given context, regardless of whether the narrator is real or hypothetical. There are two ways to report the process, one is the narrator, the other is the listener, the author introduces the dialogue in an appropriate way to express their ideas. Differences between male and female writers will inevitably lead to differences in narrative skills. Feminist narrative has also been formed.

$$
\text { (') د.عبد الرحيم الكردى، السرد في الرواية المعاصرة، دار الثقافة للطباعة والنشر ، طا، ب99 ام، ص • 11. }
$$


Feminist narrative is a multidisciplinary topic, which originated from the fusion of classic narrative and feminist literary criticism. Feminist narrative has the characteristics of political criticism in feminist literary criticism, which provides a basis for female writers to talk about themselves in the text construction. At the same time, it is also based on the theoretical framework of classical narrative, making their analysis of text more objective. Susan S. Lanser, a researcher at Princeton University in the United States, published a monograph entitled "The Narrative Act: Point of View Prose Fiction" in 1981. This pioneering work in feminist narratives has attracted widespread attention and attracted a lot of attention. Since then, researchers have produced some works combining narrative research and feminist research. And this pioneering work on feminist narratives has attracted the attention of many experts and many researchers. Some works have appeared that combine narrative research with feminist research, such as "A Loosening of Tongues: From Narrative Economy to Women Writing"(1984) from Maria M Brewer, This book is considered to be the first batch of feminist narrative research, in which Brewer studied the relationship between narrative and female writing. Warhol's book "Toward a Theory of the Engaging Narrator" (1986) also explored narrative strategies from a feminist perspective. 
Meanwhile, Lancer also published "Toward a Feminist Narratology" in the American magazine "Style" in 1986, in this article, the term "feminist narrative" is used for the first time. This article combines the characteristics of feminism and narrative, and puts forward the research objectives and methods of feminist narrative. After that, feminist narratives have gradually spread, and researchers around the world have begun to study this theme. So far, feminist narratives have become one of the important branches of narrative science. Whether in Arab countries or China, they already have relatively independent and mature theories. Differences in social backgrounds and cultural customs in different countries will inevitably make feminist narratives different. This paper aims to compare the localization of feminist narrative in contemporary China and Arab countries from the perspectives of theoretical construction and research focus of feminist narratology and the problems encountered, and briefly outline the development direction of feminist narratology.

\subsection{Theoretical construction}

Feminist narratology originated in the United States and has spread to all parts of the world. Whether it is in China or in Arab countries, feminist narratology research is derived from 
research methods under Western thinking, and then tries to achieve its localization. However, after decades of development, whether in China or the Arab countries, the original theory has been enriched to varying degrees, and combined with domestic literature research, the formation of a unique feminist narrative.

\subsubsection{China}

According to statistics compiled by Chinese researcher Yuan Panpan from Chinese academic websites( $\left.{ }^{1}\right)$, recent studies on Chinese feminist narratology are as follows:

\begin{tabular}{|l|l|l|l|}
\hline Years & $2004-2008$ & $2009-2013$ & $2014-2018$ \\
\hline Paper & 134 & 343 & 346 \\
\hline theoretical research & 32 & 55 & 44 \\
\hline $\begin{array}{l}\text { Research based on foreign } \\
\text { language text }\end{array}$ & 50 & 149 & 177 \\
\hline $\begin{array}{l}\text { Research based on Chinese } \\
\text { text }\end{array}$ & 20 & 49 & 61 \\
\hline Interdisciplinary research & 13 & 23 & 48 \\
\hline
\end{tabular}

(1)the name of website: www.cnki.net, the CNKI project is an information construction project that aims to achieve the dissemination and sharing of knowledge resources and value-added benefits to the entire society, and has created a "CNKI Digital Library", which contains Complete text information. Through cooperation with journals, publishing and related fields, cnki has developed into a world-leading online publishing platform, including journals, doctoral dissertations, master's degree thesis, conference papers, newspapers, reference books, yearbooks, patents, standards, national research And literature resources. The center's website is updated with over 50,000 documents every day. 
This table $\left({ }^{1}\right)$ is the result of a search on the CNKI website using the key words "feminist narrative" in October 2018, and it involves papers published during the 15 years from 2004 to 2018. It can be seen that the study of Chinese feminist narratives has started since the new century and has flourished in the last decade.

The earliest domestic essay on feminist narratology is Huang Bikang's "Feminist Theory of Constructing Narrative Voice" published in the 2nd issue of "Foreign Literature" in $2001\left(^{2}\right)$. This paper briefly introduces several types of narrative sounds. It should be noted that in this article it pointed out the shortcomings of Lanser's research, especially Lanser's narrowness in text selection and regional selection $\left({ }^{3}\right)$. In addition, Huang Bikang also translated Lanser's "Fictions of Authority: Women Writers and Narrative Voice" (1992). This book is by far the only complete translation of the original works of important western feminist narratology in China. It is also an important book that Chinese research scholars cannot

\footnotetext{
( 1 ) 袁盼盼, 新世纪以来的现当代女性主义叙事研究 [D] ,Shandong Normal University,2019,p3.

( 2 ) 袁盼盼, 新世纪以来的现当代女性主义叙事研究 [D] ,Shandong Normal University,2019,p9.

( 3 ) 袁盼盼, 新世纪以来的现当代女性主义叙事研究 [D] ,Shandong Normal University,2019,p9.
} 
cross over in the study of feminist narratology $\left({ }^{1}\right)$. It contains the research on the theoretical methods and practical criticism of feminist narratology. Since then, for the study of feminist narrative theory, the more important researchers in China are Shen Dan, Chen Shumei, Tang Weisheng, Yang Yongzhong, Zhou Qing, Zheng Daqun, etc. They explained the nature of feminist narratological research from different angles and aspects: the purpose of the research, the development process, and some important theories. In addition, they analyzed the shortcomings of the research and the contradictions with the Chinese social context. For example, Zheng Daqun's paper entitled "Feminist American School-A Brief Review of Feminist Narratology" outlines Lanser's feminist narratology and Ian Kaplan's feminist TV narrative theory. From this, inquire about the deficiencies of Chinese research in these two aspects. Subsequently, in the process of localization of Chinese feminist narratology, many studies flourished, for example, Ling Yue's "Feminist Narratology and Its Localization Advancement in China" (2006) raised issues that need to be considered in exploring the process of feminist narratology in China based on China's reality. Zhou Mengmeng explores the

( 1 ) 袁盼盼, 新世纪以来的现当代女性主义叙事研究 [D] ,Shandong Normal University,2019,p9. 
necessity of feminist narratology to take root in China and its evolution in China in "Feminist Narratology and Its Localization Advancement in China" (2015), Sun Guirong mainly analyzed the blind spots and misunderstandings in the practical practice of China in the past 20 years of feminist narratology in "Current Situation and Problems-Localization of Feminist Narratology" (2016).

Through statistical results and research, we can find the following characteristics in the theoretical construction of Chinese feminist narratology:

First: The Chinese feminist narrative theory is based on Western research, and it started after the twenty-first century and did not develop rapidly except in the last ten years.

Second: The theoretical construction of Chinese feminist narratives is divided into three main stages. The first stage is to introduce the theoretical basis of Western feminist narratives; the second stage is to enrich and criticize this theory and put forward this one theory. The third stage is to improve the theory by combining China's actual social background and textual information. 


\subsubsection{Arab countries}

The idea of Arab feminist narrative arose before the emergence of the official definition of western feminist narrative and it was a trend long ago. The stories of Laila Baalbaki (The Desolate Gods) (الآلهة الدسوخة) (Iأنا) (I Live) أحيا) were the first feminist narrative texts that caused widespread uproar in the Arab world, and the change of the female image being a target to being an arrow. These questions were amongst others regarding Arab culture, according to the critic Zohour Kiram especially since they were published in $1958\left({ }^{1}\right)$.

When these literary works appeared, feminism and the feminism movement were not yet popular. After the eighties of the last century, due to external economic, social and cultural factors, the women's movement gradually woke up and formed strength, which was also reflected in the field of literature, and it is a distinctive literary phenomenon, whether in the level of idea or beauty or social meaning. According to Saad Yektan, in his study entitled "The Arab Woman's Novel: Rajaa Alem is an

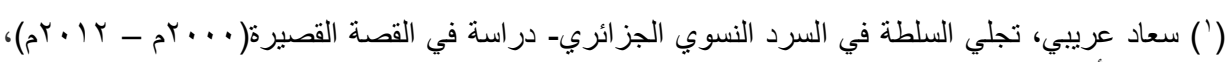

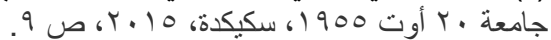


example", the theoretical system of Arab feminist narrative was formed at this time in the nineties of the twentieth century, even though Arab women have been involved in narrative writing since the end of the nineteenth century. The critic Moufid Najem added: "The past decade was considered a feminist book in the 1990s, especially in the field of fiction and criticism." He said, "With the emergence of a new generation of Arab female writers, they realized The particularity of female identity and the differences in writing in the patriarchal society are devoted to the development of feminist writing practice, enriching its meaning, developing its theoretical and aesthetic vision, thereby deepening the effectiveness of this practice and enriching feminist traditions and values'( $\left.{ }^{1}\right)$. The critic Abdullah Ibrahim said once: "The Arab feminist narrative has flourished so much that many Arab female writers living in semi-closed societies have been found in the narrative. Express it in a direct way". Ibrahim said in another interview: "Modern Arab narratives have witnessed a significant increase in feminist narratives. This is not isolated from the advancement of women's status in social and cultural life. The well-known

(') مفيد نجم ، الكتابة النسوية : إثكالية المصطلح ، التأسيس المفهومي لنظرية الأدب النسوي ، مجلة نزوى ، 
female conscious response in history, because of this, cannot be ignored".

After that, a large number of feminist novels appeared, and as many critical works gave birth, feminist narration is an important theory in it, and many researchers agreed on the dominance of manifestations, characteristics, techniques, or expressive patterns on most feminist narrative works, which makes them distinct from male narrative works. Among the notable works are "Feminist Narration: Parental Culture, Female Identity, and the Body” السرد النسوي: الثقافة الأبوية، الهوية (الت by critic Abdullah Ibrahim, In this book, the author deals with the phenomenon of feminist narration in modern Arabic literature, and the concept of "feminist narration" and the differences between women's writing and feminist writing were clarified. And the book "The Arab Feminist Narration from the plot of the event to the plot of personality" by Abd al-Rahim Wahbi revolves around the narrative of feminism, concerned with women's issues, and published a special vision for readers through it, it also confirms that the feminist narration is a literary, content and critical discourse. Just as there is a book called "Readings in a Feminist Narrative Perspective" by Dr. Hussein Al-Manasrah, this is a 
book that addresses some of the narrative issue in the narrative scene in Saudi Arabia, and it relates to some feminist narratives of novels and short stories. There are also some other studies related to feminism or to a feminist perspective in general.

Likewise, we can see that the Arab feminist narrative has the following characteristics in the development of the theory:

First, the idea of the Arab feminist narrative emerged a long time ago, and there was little work on feminism at the beginning of the nineteenth century, and the period of the complete formation of the theory system preceded China as well. But like China there is still a lot of research in this area that needs to be filled.

Second: The development of the feminist narrative with the growth of feminism and the women's movement, and the development of the feminist narrative is based on the development of feminism, whether from its early birth or the period of rapid development at a later time. At the same time, some scholars confuse feminist and feminist narratives, such as the paper "The Transfiguration of Power in the Algerian Feminist Narration - A Study in the Short Story” (تجلي السلطة في (السرد النسوي الجزائري- دراسة في القصة القصيرة), ", in the introduction 
to the book "Feminist Narration and Questions of Authority" dealing with the origins and beginnings of the Arab feminist narrative, But he often talks about feminist writing in this part.

Third, the Arab feminist narrative has not gone through the translation phase compared to China, that is, the process of introducing a large number of Western theories, and the Arab feminist narrative is a distinctive theory summarized on the basis of local women's narratives and borrowing from Western theories.

\subsection{Research Focus of Feminist Narratology in Arab Countries and China}

Feminist narration is the product of a mixture of structural narration and feminist literary criticism, as it inherits its full interest in the narrator, narrative voices, and narrative perspective. It continues to evolve over time. After the introduction of the feminist narrative, a number of articles on feminist narration appeared in Chinese and Arabic literary circles, and whether this was a theoretical completion or textual practice, it gained strong momentum to localize the female narrative and accelerate the process of localization. There is no 
doubt that each of them has its own focus in the development process, and the areas of research and points of focus differ due to the different social and cultural contexts, literary traditions and other factors in the process of localization.

\subsubsection{The Research Focus of Chinese Feminist Narratology}

It has been mentioned above that "feminist narration" entered the Chinese academic circle as a new concept in 2000. Many researchers introduced it to readers and the Chinese literary circle, and some scholars studied feminist narration more and more and presented various aspects of his theory and research methods, and abundant research appeared in that time. However, in the first period of the twenty-first century, China's interest and acceptance of the feminist narrative remained mostly theoretical.

Since 2005, some textual analysis studies based on feminist narratives have begun to appear, such as Ling Yu's "Classical Text of Feminist Narratives-On Sisi's ((Mourning Breast))" ( ${ }^{1}$ )published in 2009 in Literary Contest Chinese researchers use feminist narratology to analyze specific textual events from domestic and foreign writers, and study the general 
narrative strategies of selected writers, comparing female narrations of different writers from the perspective of feminist narratives.

Afterwards, papers using feminist narrative theories continue to appear. For example, Wang Xiaoying published a paper entitled "The Art of Subversion-((The Light of Father's Smile))"in the Second Issue of Contemporary Foreign Literature in 2006. The paper explains the contemporary narrative structure and voice of American writer Alice Walker. In addition, Liu Bingjie published a paper titled "The Silent Authority in the Narration of ((Happiness Overdone))" in the first issue of the Journal of zhongbei University of China (Social Science Edition) in 2019, Her thesis revolves around the narrative sound analysis of the novels of Canadian writer Alice Monroe. There are also some papers on the feminist narrative by Arabic works, such as the graduation thesis of "((Zahra's story)) Construction of female authority in narrative" (2015) by Zhang Yu of Beijing Foreign Studies University, Her thesis discussed building narrative voices of males and females in the novel and building women's power from the perspective of feminist narration. In addition, in 2016, There is another thesis entitled "((Black is for you $))$ the construction of female authority in the narrative" from Hong Tu of Beijing Foreign 
Studies University. Her thesis focuses on establishing female power in the narrative and voice expression of the novel. In addition, there are also many feminist narrative studies on Chinese texts. For example, A letter titled "Interpretation of the Feminist Narration of ((The Golden Lock))" by Lu Mei Juan and Peng Wen Juan in Issue 4 of the 2008 "Anhui Literature (second half)". The paper deals with forms of narration and sexual authority. As well as the paper "Narrative Power: Feminist Narrative Studies of the Novel ((Good Luck Club))" from Wang Meng Yuan, the first issue of magazine "English Abroad" for the year 2019, the paper is related to the analysis of narrative voice, narrative interference, and narrative power.

These examples are endless, from the analysis and summarization above; we can see that the focus points for the feminist narrative in China are the following aspects:

First: The focus points of the Chinese feminist narrative on analyzing and criticizing texts using feminist narratives in recent years.

Second: From the data in the table above and the explanation above, it can be noted that the scope of text search is also focused mainly on foreign texts. 
Third: Most of the research findings are published in the form of academic papers and articles and theses, and there are a few systematic studies in the form of literature and books.

\subsubsection{Research Focus of Feminist Narratology in Arab Countries}

After introducing the western feminist narrative into Arab countries, it made great progress as well. Many critics and researchers were quick to express their opinions in this field. Many theses and fruitful studies were shown. For example, an article entitled "Narration and the female vision of the world" (السرد والرؤية الأنثوية للعالم) from the scientist Abdullah Ibrahim in "Semiotics"(مجلة سيميائيات), This research revolves around the great progress in the Arab feminist narrative after the narration was central to masculinity in the second half of the twentieth century, and then the development of feminist ideas in novel writing through feminism.

An article entitled "The Female Narration in Contemporary Algerian Literature” (السرد النسائي في الأدب الجزائري المعاصر) in Magazine "Researches in Algerian Language and Literature"

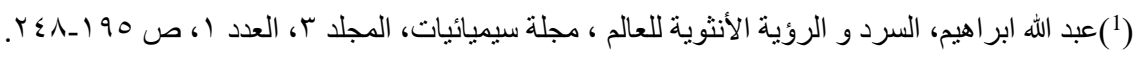


by researchers Zaghina Ali, Mafquda Saleh and Aliah Ali. This thesis deals with three topics: the concept of feminist literature, the relationship of postmodernism with feminist literature in contemporary Arab thought and postmodern manifestations in contemporary Algerian feminist narration. From these points, it clarifies and interprets Algerian novels.

More research findings and the focus of the Arab feminist narrative are reflected in literature and books. For example, the book "Feminist Narratives in the Emirates - Critical Approaches to Vision and Formation" (السرديات النسوية في الإمارات - مقاربات نقدية في الرؤية والتشكيل published by Sharjah Culture and ليلى ( Information Department by researcher Laila Bint Youssef (بنت يوسف), which is the book that won the award for the best book for an Emirati author - Dubai Cultural Award for Creativity 2014-2015. Her book deals with the topics of the female novel In the Emirates and narrative structure techniques in the Emirati women's novel. As a result of the results, he discovered the writer's interest in details, small particles, and a tendency towards curiosity in the narration, a feature of writing for Emirati writers, and this feature is related to the psychological characteristics of women. 
And the book "The Perspective on Feminist Narration - A Short Story as an Example - 1970-2000” وجهة النظر في السرد

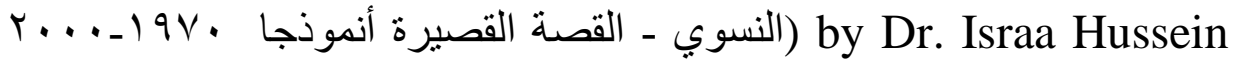
Jaber) (إسراء حسين جابر), is a book that deals with the characteristics of feminist narration in the short story at a certain time, and believes that feminist narration is a product that carries uniqueness or distinction, and emphasizes in her book Feminist narratives in this period are different than before due to the social reforms of the time. The book is divided into four chapters to discuss the image of the external narrator, "the paradoxical vision", the levels of view in the feminist narrative, and character building in the feminist narration.

There is a book entitled "Feminist Narration; Parental Culture, Female Identity, and the Body” (السرد النسوي: الثقافة from the hand of researcher Abdullah Ibrahim (عبد الله ابراهيم), and the writer addressed the phenomenon of feminist narration in modern Arab literature in his book, differentiated between women's writing and feminist writing, criticism of the prevailing patriarchal culture, and the belief of the body Women are an essential component of writing, and all of this should be done within the framework of feminist 
thought, and seeks to formulate female concepts through narration, and the dismantling of the patriarchal system by exposing its impotence.

Moroccan researcher Mohamed Moatasem (محمد معتصم) published the book "Women and the Development of the Arab Narrative: Women, Feminism, and Femininity” ( المرأة وتطوير on “Now Publishers and Distributors" in Amman, Jordan in 2019. The author defined the female creative experience in narrative writings; this is to demonstrate that the Arab women writers have played an effective role in developing and enriching the modern and contemporary Arab narrative body. He also said: "female writing has concerned itself with feminist issues, but with the moral, aesthetic, and artistic aspect of narration predominant, or it is writing that combines women's issues with narration issues."

Moroccan critic and writer Aziz Al-Arbawi (عزيز العباوي) published the book Banaan "Feminist Narrative Narration: Freedom, Self, Body” (السرد الروائي النسوي: الحرية، الذات، الجسد) in Dar Dal for publishing the distribution in 2019, and his book 
gives a vision that relates to an intellectual definition that defines the image of women in feminist narrative writing and that it is diverse, it is no longer the fixed pattern Like the past.

In addition, there are a few theses that use feminist narration to analyze the text, for example "Feminist Narratives - An Empirical Study on Raja Alam's Novels” ( السرديات النسوية - دراسة (تطبيقية على روايات رجاء عالم) from researcher Fatima Bint Faisal Al-Otaibi (فاطمة بنت فيصل العتيبي) of King Saud University in Riyadh for the year 2009. Her thesis deals with the elements of narration in "Raja Al-Alam" (رجاء العالم), and explain how to build personality in the novel using the feminist narration theory.

Through the examples and analyzes mentioned above, we can clearly see that the focus points for the feminist narrative in the Arab world are in the following aspects:

First, the research focuses mainly on the theoretical system, and there are a few research and practical studies that use theory in comparison with China. 
Second: Although there are many theoretical studies, most of them focus on the issue of Emiratisation and apply with the context of Arab society to form its own set of theory.

Third: Unlike China, the results of Arab feminist narrative research have been systematically published in books and literature, often with a few separate academic articles.

\subsection{The obstacles of feminist narrative research in China and the Arab world}

Feminist narratives began in the 1980s and are still in development. They have been present in China and the Arab world for decades, but the theoretical translation and application of the theory has not been long. Feminist narratology came into being in the United States. It conforms to the cultural background of the West, but the huge differences between Eastern and Western cultures will inevitably affect its localization process and will also face many challenges. Therefore, no matter it is China or the Arab countries, there will be many difficulties and challenges in solving the localization of feminist narratology. 


\subsubsection{The obstacles of feminist narrative research in China}

The feminist narrative in the localization of China faces the following difficulties:

First of all, there are many academic papers on feminist narratology in China, but the related monographs are very limited. Except for these two books "Fictions of Authority: Women Writers and Narrative Voice” (1992) which translates Huang Bikang from Lancer, and "The Western Feminist Narration: Classics and Post-Classics" co-authored by Shen Dan and Wang Liya. The first one is the translation of Western feminist narratology theory. In-depth research in this field, only one chapter of the second book is about feminist narratology. Therefore, feminist narratology is still in its infancy in China.

Second, there are many academic articles on text analysis and a message to discuss the theory a few. After the introduction of the feminist narrative in China, there were a large number of papers on theory, but most of them focused on the interpretation of specific literary works, and there were a few papers on the feminist narrative itself. According to the relationship between theory and practice, the development of the feminist narrative theory is inseparable from the concrete 
text analysis practice, which is conducive to enhancing its theoretical reliability and promoting its development. However, there are many text analysis practices and there is no integrated theory that it considers the basis of this study. The Chinese feminist narrative still faces the challenge of constructing a systematic theory.

Third, there are many theoretical studies in the West, and few results from Chinese theoretical studies. Most articles and messages focus on the study of Western feminist narrative theory, and rarely involve the development of this theory in the context of Chinese historical culture. The feminist narrative arose out of the Western world, but when it entered China it must apply to Chinese contexts and circumstances and become the theory of China. This made the localization process more difficult in China.

Fourth, the time for the introduction of the western feminist narrative into China is not long, and although it has made some achievements, it is still in a marginal place, so the scholars and researchers who study it are still limited.

\subsubsection{The obstacles of feminist narrative research in the Arab countries}


As explained above, feminist narration is a multidisciplinary theory based on feminism and narration, and from this neighborhood, the obstacles of feminist narration in Arab countries are divided into two aspects: the obstacles of feminism and the marginalization of feminist narration.

The biggest problem in the feminist narrative in the Arab countries is not the development of the feminist narrative itself compared to China, but rather the obstacle to external masculinity. Of course, masculinity impedes the development of the women's movement to some extent in other countries and regions as well, but because of historical, religious, social, and other factors Among the factors in Arab countries, women do not have the tradition of participating in society and writing, and therefore resistance due to masculinity will be relatively more difficult and the male culture prevailing in Arab societies has created divisions of language, male language and female language as Fatima bint Faisal Al Tepe (فاطمة بنت فيصل العتيبي) in the theses of the Master: "give patriarchal culture man speech recipe power, with a clarity and certainty and focuses on hard, means that issues important like war and equestrian life, while women focus on emotions, fragile about marriage, 
motherhood, children and conversations, and the details of daily junk" $\left.{ }^{1}\right)$.

Saffouri (صنوري) believes that the feminist narration: "It is that narration that a woman writes is free from the shackles of male literary norms, relying on her own experiences, making her first concern the cause of women and its position in the center of the literary text ..." $\left.{ }^{2}\right)$. The first obstacle in the feminist narration is the position of women, without adhering to the rules of writing, according to the words of Saffouri.

Like China, the Arab feminist narrative emerged as an emerging system in the late nineteenth century. Although he has made significant progress, he remains marginalized, and scientists and researchers have not invested in this study with great enthusiasm. There are not enough studies and papers published. But with the development of feminist literature, the feminist narrative is expected to evolve rapidly.

$$
\begin{aligned}
& \text { (')فاطمة بنت فيصل العتيبي (^ . r)، السرديات النسوية: دراسة تطبيقية على روايات رجاء عالم، جامعة الملك }
\end{aligned}
$$

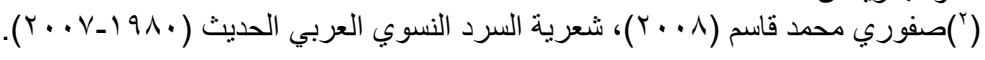




\subsection{The direction of the development of the feminist narrative in the future}

Feminist narration emerged nearly forty years ago, and after many scholars and researchers continuously improved its theoretical framework, feminist narration became a comprehensive, multidisciplinary concept. However, with the continuous development and completion of the feminist narrative, many scholars and researchers have questioned his research method. The inventor of the feminist narration of Lancer in a paper entitled "Are We There Yet? The Intersectional Future of Feminist Narratology" at the Second International Conference on Narratives and the Fourth National Conference on Narratives, She said: "Thinking" of the intersection of roads requires that women do not assume that these patterns exist naturally, and we are not supposed to predict them, but must be observed through actual experience, and not confirmed by the (feminist) mind, which is exactly common approaches in Early feminist narration (including my own business $)\left({ }^{1}\right)$. She believes that early feminist narrative research was based on feminism and classical narration, and the 
group of women has been analyzed according to the naturally defined pattern, in other words, in feminist narration most researchers are biased towards feminism in text analysis, and they neglect the logic of the classic narrative, what Lancer advocated, Now, the research trend in this field will change from feminism to narrative.

As Lancer said in a paper titled "Toward (a Queerer and) More (Feminist ) Narratology": "If I encourage narrative research to be more queer and more feminist in the 1980s and 1990s, I Now I encourage feminist and queer research papers that are more narrative close to " $\left.{ }^{1}\right)$. She emphasized: "In this letter, I insist on using" narration "from start to finish, and ignore pressure to avoid the use of feminism and the theory of queer narration, as the title emphasizes, I strongly support maintaining the concept of "narration" and the critical practice of "narration" because narration is strict in structure And I have tried to explain that the more classic narrative explorations not only help us clarify the text, but also help us clarify the social context of the text "(Lancer: 2019, p. 63).

${ }^{1}$ )建构(更酷儿)和更加兼容的(女性主义)叙事学, 苏珊.S. 兰瑟; 胡全生, 《学术论坛》2019年第1期,p63. 
Meanwhile, at the Academic Seminar "Chinese-Western Dialogue in Contemporary Narration Theory" held by Shanghai Jiaotong University from December 7 to 8, 2019, Professor Du LanLan delivered a speech entitled "Queer in Narration: From Feminist Narration To the Queer narration", and talked about the new development of the feminist narrative in recent years the rise of the Queer narration.

This series of ideas and responses has shown a new research direction for feminist narrative and the development trend of feminist narration, i.e. finding a new balance between feminism and classical narration and this is the future of feminist narrative of the world. 


\section{References}

1. Chen Shunxin, Narrative and Gender in Chinese

Contemporary Literature, Beijing University.1995.

2. Shen Dan, Narratology and Stylistics of Fiction, Beijing University Press, 2004.

3. Shen Dan, Wan Yali, Western Narratology : Classics and Post-classics, Beijing University Press, 2010.

4. Sun Guirong, Multiple Expressions of Gender : Studies of Female Discourses of Chinese,Contemporary Literature, People's Literary Press, 2011.

5. Susan. Lanser, Fictions of Authority : Female writers and Narrative Voices, Beijing UniversityPress. 2002.

1. عبد الرحيم الكردي، السرد في الرواية الدعاصرة، دار الثقافة للطباعة

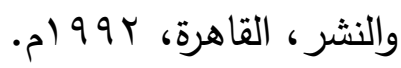

r. رشيدة بنمسعود، جمالية السرد النسائي، شركة النشر والتوزيع المدارس، الدار

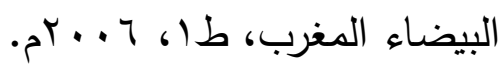

r. زهور كرام، السرد النسائي العربي مقاربة في المفهوم والخطاب، شركة النشر

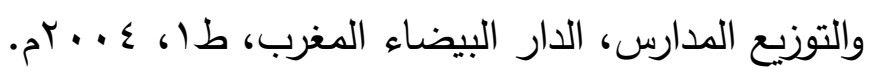


ع. عبد العال بوطيب وآخرون، الكتابة النسائية التخييل والتلقي، اتحاد كتاب

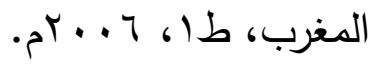

هـ ليندا عبد الرحمن عبيد، تمثيلات الأب في الرواية النسوية العربية المعاصرة، دار فضاءات للنشر والتوزيع والطباعة، الأردن، طا، V • . rم.

7. محمد معتصم، المرأة والسرد، دار الثقافة، الدار البيضاء المغرب، طا،

$$
\cdot p^{\prime} \cdot \varepsilon
$$

V. محمد نجيب العمامي، في الوصف بين النظرية والنص السردي، دار محمد

$$
\text { علي للنشر ، تونس، طا، } 0 \text {. . بم. }
$$

^. سعد يقيطن، الرواية والتراث السردي، من أجل وعى جديد بالتراث السردي، رؤيسة للنشر والتوزيع، القاهرة، طا، 7 ـ . بم.

9 . عبد الله إبراهيم، السردية العربية، بحث في البنية السردية للموروث الحكائي

$$
\text { العربي، المركز الثقافي العربي، بيروت، } 99 \text { ام. }
$$

• زقاق المدق، ديوان المطبوعات الجامعية، الجزائر، 990 ام. 